\title{
Human Health Risk Assessment in Shahid Rajaee Container Terminal
}

\author{
Abdollah Jafari ${ }^{1}$, Saeid Givehchi ${ }^{2}$, Mahnaz Nasrabadi ${ }^{1}$ \\ ${ }^{1}$ Department of Environment Management (HSE), Faculty of Engineering and Technology, Zahedan Branch, Islamic Azad University, \\ Zahedan, Iran \\ ${ }^{2}$ Faculty of Environment, University of Tehran, Tehran, Iran \\ Email: ^Iran.givechi@ut.ac.ir
}

How to cite this paper: Jafari, A., Givehchi, S. and Nasrabadi, M. (2016) Human Health Risk Assessment in Shahid Rajaee Container Terminal. Open Journal of Ecology, 6, 686-698.

http://dx.doi.org/10.4236/oje.2016.611063

Received: April 18, 2016

Accepted: October 28, 2016

Published: October 31, 2016

Copyright $\odot 2016$ by authors and Scientific Research Publishing Inc. This work is licensed under the Creative Commons Attribution International License (CC BY 4.0).

http://creativecommons.org/licenses/by/4.0/

\begin{abstract}
As the ports play a prominent role in the national economy of the countries and a number of factors such as safety condition of the port and low rate or non-occurrence of accidents are greatly important for being selected as a destination for cargo owners to bring their vessels and cargo therein, giving due care to safety related issues in ports and harbors is among jurisdictional and sensitive duties of the authorities in ports and maritime areas. Enjoying some $3000 \mathrm{~km}$ of marine coastlines and more than 10 commercial ports throughout the country, Iran is no exception where its ports are responsible for cargo import and export. In this respect, container terminals are one of the high-risk areas in ports requiring extensive care of the pertaining authorities to take appropriate measures to maintain safety standard there. One of the significant methods and techniques for the risk assessment is P\&HRAM as to the containers terminals. This method has been employed in this research taking into account the operation attributes of the works in ports and harbors. This method provided appropriate answers to the research questions in that it was predicted that the great part of the activities in container terminal poses a higher risk from human perspective than expected requiring some measures to be taken to mitigate the risks to a tolerable level. This research was conducted and the results demonstrated that more than $75 \%$ of the risks in container terminals are higher than acceptable level about which some measures were taken and the risks were reduced to $100 \%$ lower than tolerable level.
\end{abstract}

\section{Keywords}

Human Risks, Container Terminal, Safety Management

\section{Introduction}

Port terminals and container terminals in particular are considered high-risk areas in 
ports [1]-[3]. The high number and severity of the incidents in Bandar Shahid Rajaee port which is the largest container port of the country and the region are indicative of the fact that such factors as diversity of the tools and equipment, the frequency of the port workers, variety of the work systems, diversity of the import and export cargos, huge volume of cargo traffic and incoming and outgoing vehicles, different working hours, the number of the port terminal operators, the large scope of work have made the container terminal among the high-risk areas [3] [4].

The safety is defined farness from the unacceptable level of risks [4] [5]. This means that the lower likelihood of danger, the lower possibility of risk which leads to safety. The risk management is a systematic and logical process for the purpose of identification, analysis, assessment, control, information associated with any given activity and also striking an acceptable balance between the cost incurred by an incident and the cost associated with the precautionary measures to lower the risks [1] [4] [6]. Therefore, for the management of the risks in ports, firstly, the risk associated with the activities in the port should be established and then analyzed in a systematic process [7].

\section{Research Questions}

- Are the risks identified in respect of manpower are tolerable [2]?

- Are the intolerable risks identified are possible to be mitigated to a tolerable level by employment of the risk assessment methods and tools [2]?

\section{Research Objectives}

The main objective of the research is the assessment of the risks associated with manpower in container terminals [3].

\section{Methodology and Data Collection}

In this research library method was employed including the study of books, manuals, guidelines, dissertations, articles (domestic and international), websites and literature as well as the field study [3] [4]. Also in this research the statistics of the manpower incidents in SINA container terminal was used. In order to answer the research questions, a data collection tool was needed. In this research internet and incidents statistics were used as well.

Data collection method in this research is a field-basis one and other methods such as the study of literature, documents and the resources of related organizations were used as well [5].

\section{Data Analysis Method}

In this research, the date has been collected using P\&HRAM Risk Assessment method. Following analysis of current situation of the container terminal and establishment of the operational procedures and the occupations being conducted by the manpower in the terminal, the risks will be identified and their assessment will be made. Given the 
findings of the information gained in this process, the risks will be valued in terms of frequency and severity [1].

\section{Hormozgan Province}

As shown in the (Figure 1), Hormozgan province is located in southern Iran with a total area of 70,697 square $\mathrm{km}$. It ranks $8^{\text {th }}$ among the Iranian provinces. From the north and north-east, it borders Kerman Province and from west and north-west it borders Fars and Bushehr Province and in the east it borders Sistan \& Baluchestan Province and at the south it borders Persian Gulf. As per the statistics of 2011, the population of Hormozgan province amounts to 1.5 million people. As a center of the Hormozgan province, Bandar Abbas is one of the biggest port cities of Iran which is a center for commercial and economic activities. Situated in the Strait of Hormoz bordering Persian Gulf and Oman Sea, Bandar Abbas plays an important part in the import and export of cargo in the country. Significant marine infrastructures such as Shahid Rajaee port, Bandar Abbas Oil Refinery, Al-Mahdi Alumina Factory, Persian Gulf Ship Yard, Steel \& Cement Manufacturing Factory are located in this province. Hormozgan province hosts more than 70 ports and berths with manifold usage such as commercial, oil, fishing and etc. the ports located in this province are: Shahid Rajaee, Shahid Bahonar, Lengeh, Kish, Bahman, Gheshm, Jask, Khamir, Tiab the location of which are demonstrated on the satellite image. All of the said ports are operating under the authority of Hormozgan Port and Maritime Authority [6] [7].

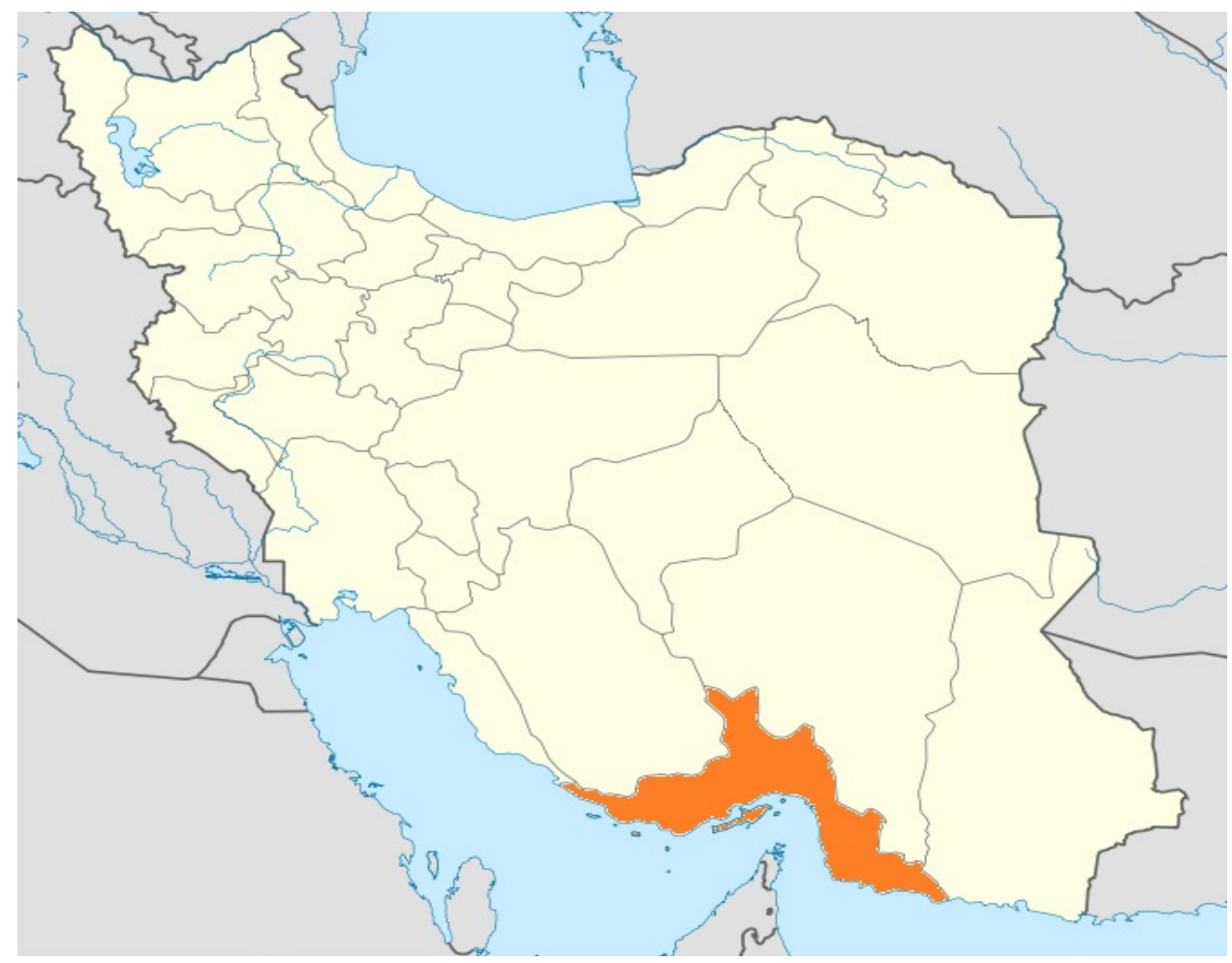

Figure 1. The Hormozgan province map and details. 


\section{Shahid Rajaee Port Complex}

As shown in the (Figure 2), Shahid Rajaee Port Complex is located in $23 \mathrm{Km}$ west to Bandar Abbas. Its geographical position is latitude $27^{\circ} 07^{\prime} \mathrm{N}$, longitude $056^{\circ} 04^{\prime} \mathrm{E}$, in the north of Qeshm Island and Hormuz strait. Its total area is about $2 \mathrm{Sq} \cdot \mathrm{Km}$ from which $7.5 \mathrm{Sq} \cdot \mathrm{Km}$ is dedicated to Supportive activities.

In 1983, whit the opening of the first terminal container of Shahid Rajaee Port, this port complex was officially opened and loading/unloading operations were started [7] Shahid Rajaee Port Complex enjoys many advantages include enjoying a unique strategic position, access to international open waters via Persian Gulf, access to international rail and road networks, closeness to free zones of Kish, Qeshm and ports located in Persian Gulf, taking advantage of modern facilities and equipment's, and etc. It is also necessary to note that Qeshm Island protects Shahid Rajaee Port against high waves of Persian Gulf and Oman Sea [7] [8].

\section{Research Methodology}

The risk assessment was carried out using Port and Harbor Risk Assessment Based on P\&HRAM Matrix [1].

In summary, the above methodology includes:

- The methods which identifies the risks of the port activities

- Safety management system used controls the identified risks

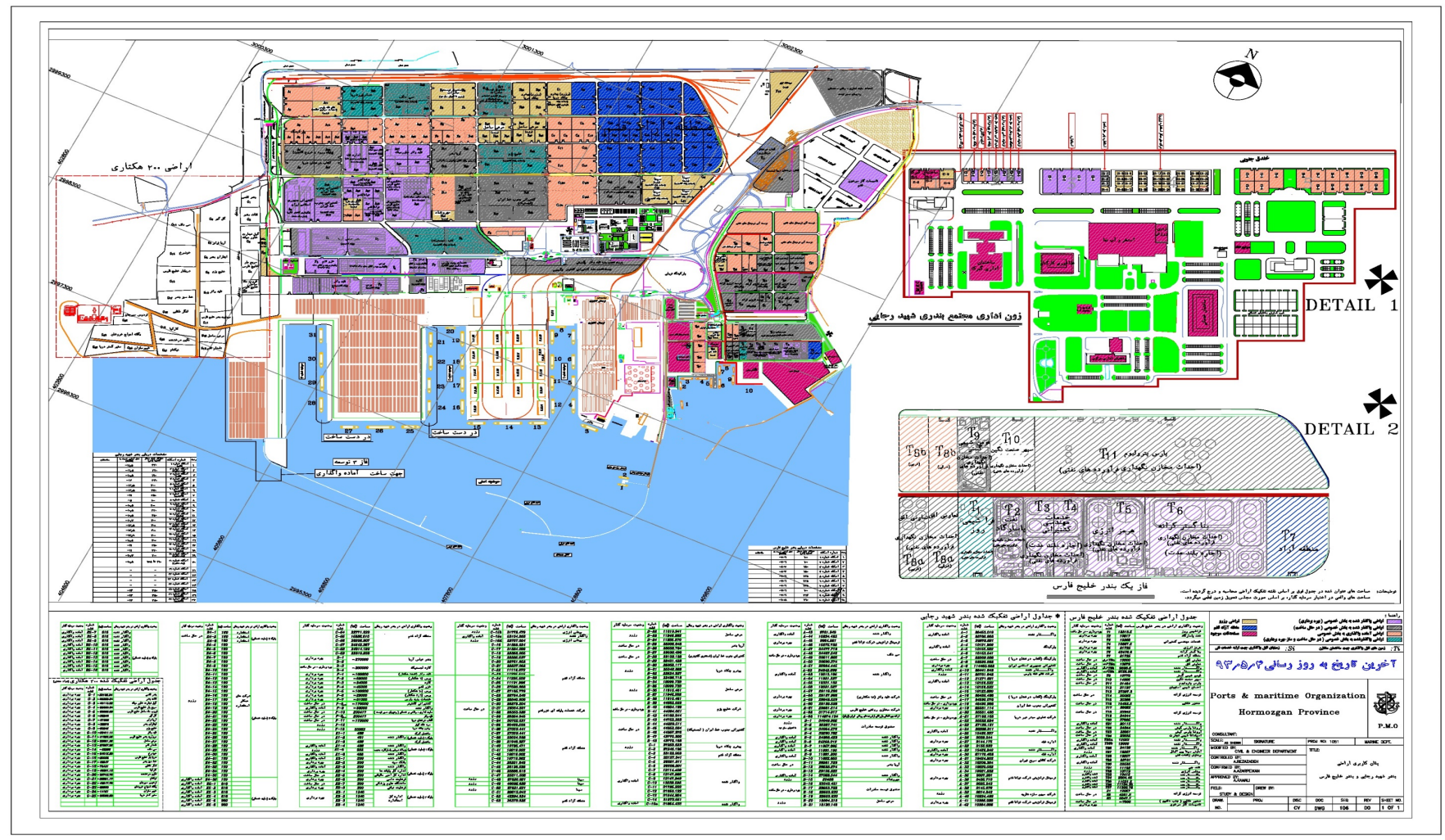

Figure 2. Shahid Rajaee port map. 
In the past, a safety management system on the basis of the incidents occurred and learning lessons from them was in place [8]. While, today, it is necessary to use the proactive risk assessment systems to manage the safety [8]. It, definitely, entails identification of the risks and their minimization in the safety management process [1] [9] [10].

The safety is more important for the those companies and organizations operating in port and maritime fields due to material and spiritual losses arising from the incidents [1] [10] [11]. This method of risk assessment begins with identification of the risks including:

- Human resources

- Environment

- Assets (equipment, installations, tools and etc.)

- Port stakeholders

When a risk is identified, its frequency and severity should be established as well. On this basis, a risk consists of:

- Frequency of occurrence

- Consequence and its potential

Actually, the likelihood of occurrence of incidents is a coefficient of its frequency and its severity and its consequence. In some cases, risks include a simple correlation between its severity and its likelihood of occurrence but in some other cases this correlation is more complex [1] [12].

Taking the account of the above, the risks in the port and harbors is assessed using the Matrix 1 as shown in the Figure 3.

This matrix is consisted of traceable and assessable cells. The above matrix is an example of the risk division diagram consisting of three sections:

1) Acceptable risks

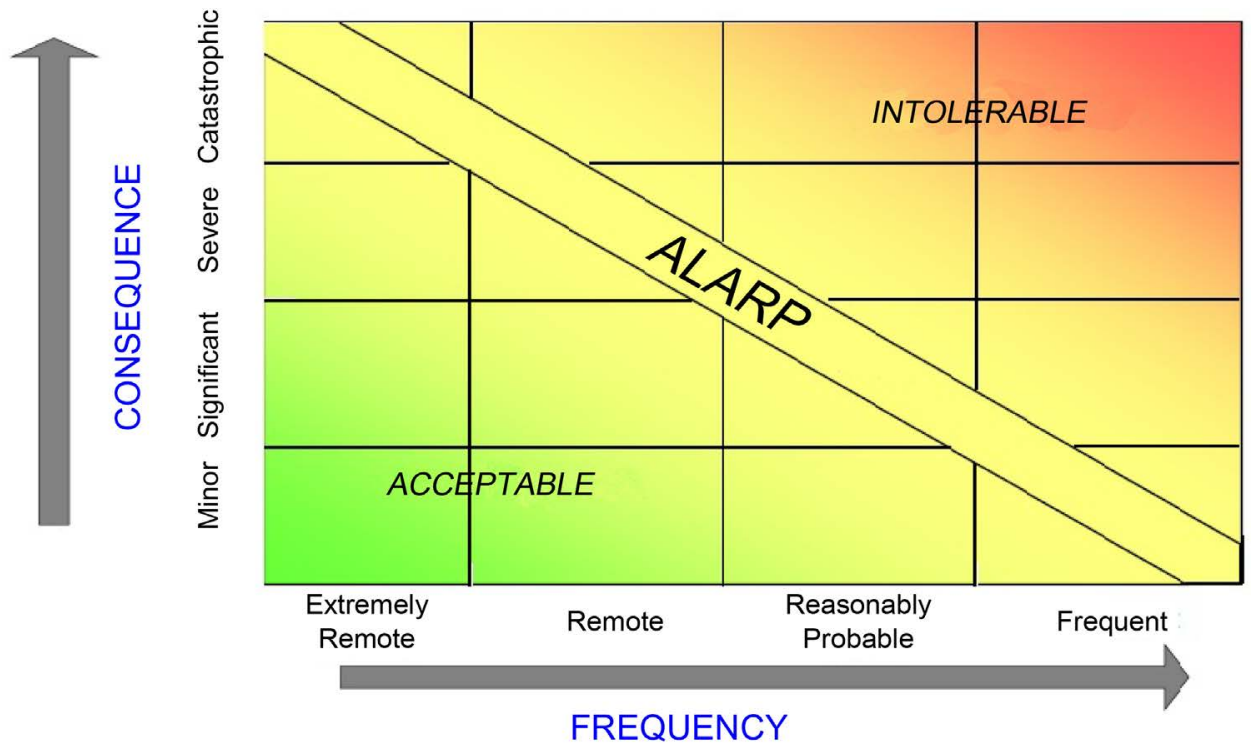

Figure 3. The risks in the port and harbors are assessed using the Matrix 1. 
2) Risks acceptable in particular circumstances

3) Intolerable risks

When the risk matrix is developed containing the lines showing acceptable risks and put available to the user, then he/she he will understand that for what kinds of risk he/she should endeavor and make necessary planning. Upon recommendation of the risk mitigation solutions, the safety management may decide what recommendations are to be implemented for which necessary studies should be conducted as well [1]. The level of the acceptable risks is not established by the safety technicians or risk evaluators but it is to be determined by the safety management [1] [12] [13].

\section{Port and Harbor Risk Assessment Structure (P\&HRAM)}

Using this method, a compatible framework can be developed for the risk assessment and safety management system in ports because it is a proposed standard method for rectification of the current situation of the risk assessment in ports and harbors as shown in the Table 1 [1] [12] [13].

Quantitative risk assessment entails updated values as well as quantitation of the consequences arising from the incidents. In safety management system, these consequences fall into four categories as shown in the Table 2: 1) Human casualty, 2) Damage to asset (including: property, cargos, installations, equipment and vessels), 3) Environmental damages (particularly marine environment) and 4) Damage to stakeholders (adverse impacts of the incidents to the operation of a port negatively affecting the interest of the stakeholders) [1]. Prominent advantages of this categorization of incidents include giving a clear and understandable quantitative definition of incidents and risks in port areas and establishing the damages in quantitative and financial manner [1] [14].

Ultimately, definitions on different cases have been translated into figures to be used for the risk assessment by the port operators and local associations. These figures vary between $0-10$ as shown in the Table 3 [1].

After quantification of the risk with a view to help safety officers to easily assess and classify risks, the types of the risks are categorized into 6 groups:

- 0 - 1: Negligible Risk

- 2 - 3: Low Risk

Table 1. Frequency rate of the incidents.

\begin{tabular}{ccc}
\hline No & $\begin{array}{c}\text { Standard } \\
\text { (AS/NZS 4360) }\end{array}$ & Definition \\
\hline F1 & Frequent & $\begin{array}{c}\text { Incidents likely to occur once in a week up to once a year } \\
\text { Incidents likely to occur once in a year up to once every } 10 \text { years }\end{array}$ \\
F2 & Likely & Incidents likely to occur once in 10 years up to once in 100 years \\
F4 & Possible & Incidents likely to occur once in 100 years \\
F5 & Unlikely & Incidents likely to occur less than once in \\
100 years in a port world-wide
\end{tabular}


Table 2. The scale of the risks in terms of consequences.

\begin{tabular}{|c|c|c|c|c|}
\hline Rank & Iman casualty & Asset & nvironment (NZD) & Stakeholders (NZD) \\
\hline $\mathrm{Co}$ & $\begin{array}{l}\text { Insignificant } \\
\text { (without } \\
\text { injuries or } \\
\text { with } \\
\text { insignificant } \\
\text { injuries) }\end{array}$ & $\begin{array}{l}\text { Insignificant } \\
(0-10 \text { NZD })\end{array}$ & $\begin{array}{l}\text { Insignificant } \\
(0-10 \text { NZD })\end{array}$ & Insignificant (0 - $10 \mathrm{NZD})$ \\
\hline $\mathrm{C} 1$ & $\begin{array}{l}\text { Minor (with a } \\
\text { minor injury) }\end{array}$ & $\begin{array}{l}\text { Minor } \\
(10-100 \\
\text { thousand } \\
\text { NZD })\end{array}$ & $\begin{array}{l}\text { Minor-minor } \\
\text { environmental } \\
\text { pollution }(10-100 \\
\text { thousand NZD) }\end{array}$ & $\begin{array}{l}\text { Minor. Decline in port social } \\
\text { credibility and income } \\
(10-100 \text { thousand NZD })\end{array}$ \\
\hline $\mathrm{C} 2$ & $\begin{array}{l}\text { Moderate } \\
\text { (without } \\
\text { multiple } \\
\text { minor injuries } \\
\text { or one major } \\
\text { injury) }\end{array}$ & $\begin{array}{l}\text { Moderate (100 } \\
\text { thousand - } 1 \\
\text { million NZD) }\end{array}$ & $\begin{array}{l}\text { Moderate. } \\
\text { Environment } \\
\text { pollution limited to } \\
\text { the port and harbor } \\
\text { (100 thousand - } 1 \\
\text { million NZD) }\end{array}$ & $\begin{array}{l}\text { Moderate. Huge decline in port } \\
\text { credibility and temporary disruption } \\
\text { of the port activities (100 } \\
\text { thousand - } 1 \text { million NZD) }\end{array}$ \\
\hline $\mathrm{C} 3$ & $\begin{array}{l}\text { Major } \\
\text { (multiple } \\
\text { injuries or } \\
\text { one dead) }\end{array}$ & $\begin{array}{c}\text { Major } \\
(1-10 \text { million } \\
\text { NZD })\end{array}$ & $\begin{array}{l}\text { Major. } \\
\text { Environmental, gas } \\
\text { and chemical } \\
\text { pollution spreading } \\
\text { over the port } \\
\text { confinements } \\
(1-10 \text { million NZD) }\end{array}$ & $\begin{array}{l}\text { Major. Huge decline in port } \\
\text { credibility and blockage in port } \\
\text { access channel for few days and } \\
\text { negative impact on port trade and } \\
\text { possibility of losing part of the trade } \\
\quad(1-10 \text { million NZD) }\end{array}$ \\
\hline & $\begin{array}{l}\text { Catastrophic } \\
\text { (heavy } \\
\text { casualties) }\end{array}$ & $\begin{array}{l}\text { Catastrophic } \\
\text { (more than } 10 \\
\text { million NZD) }\end{array}$ & $\begin{array}{l}\text { Catastrophic. } \\
\text { Pollution requiring } \\
\text { international financial } \\
\text { aid (more than } 10 \\
\text { million NZD) }\end{array}$ & $\begin{array}{l}\text { Catastrophic. Huge decline in port } \\
\text { credibility in international level and } \\
\text { serious disruption in port activities } \\
\text { and long-term losing of trade (more } \\
\text { than } 10 \text { million NZD) }\end{array}$ \\
\hline
\end{tabular}

Table 3. The risk assessment consequences.

\begin{tabular}{ccccccc}
\hline & C4 & $\mathbf{5}$ & $\mathbf{6}$ & $\mathbf{7}$ & $\mathbf{8}$ & $\mathbf{1 0}$ \\
& C3 & 4 & 5 & 6 & 7 \\
Consequences & C2 & 3 & 3 & 4 & 6 & 9 \\
& C1 & 1 & 2 & 2 & 3 & 6 \\
& C0 & 0 & 0 & 0 & 0 & 0 \\
\hline Frequency & & F5 & F4 & F3 & F2 & F1 \\
\hline
\end{tabular}

- 4 - 5: Tolerable Risk

- 6: Heightened Risk

- 7 - 8: Significant Risk

- 9 - 10: High Risk

\section{The Findings of the Risk Assessment of the Current Operational Procedures in SINA Container Terminal}

Following the risk assessment of the operational procedures of the SINA Container 
Terminal in Shahid Rajaee Port (Bandar Abbas Port) [14] using P\&HRAM and establishing the risks with assigning relevant figures, a number of appropriate recommendations were given as to how to cope with and minimize the identified risks.

As shown in the Table 3, frequency was multiplied by the severity of the risk and the result was assumed to the risk figure of each current operational process and the level of each was established using P\&HRAM. The results are showing in the Table 4.

\section{Clarification on the Results of the Risk Assessment of the Current Operational Procedures in SINA Container Terminal, Bandar Abbas Port}

The risk assessment in the container terminal shows that out of 35 operational procedures in the terminal some 26 procedures (75\%) are higher than ALARP. This indicates that the operation in the terminal is high risk requiring control measures to lower the risk. After implementation of the recommended control measures, it was seen that the risk of all operational procedures $(100 \%)$ lowered to tolerable level in a way that continuation of the activities in the terminal can take place without a particular problem. On the basis of the results of the risk assessment in different stages, the procedures are showing in the Table 4:

1) Risk assessment of the ship operational procedures

- Initial risk assessment (R1): the risk of the $75 \%$ of operational procedures proved to be higher than ALARP level.

- Secondary risk assessment (R2): the risk of the $100 \%$ operational procedures proved to low and tolerable level.

2) Risk assessment of the berth operational procedures

- Initial risk assessment (R1): the risk of the $75 \%$ of operational procedures proved to be higher than ALARP level.

- Secondary risk assessment (R2): the risk of the $100 \%$ operational procedures proved to low and tolerable level.

3) Risk assessment of the port areas operational procedures

- Initial risk assessment (R1): the risk of the $65 \%$ of operational procedures proved to be higher than ALARP level.

Table 4. The results of the risk assessment of the current operational procedures in SINA Container Terminal, Bandar Abbas port on the basis of the current operational procedures.

\begin{tabular}{|c|c|c|c|c|c|c|c|}
\hline \multicolumn{2}{|c|}{ Risk consequence } & $\begin{array}{c}\text { Negligible } \\
\quad(0-1)\end{array}$ & $\begin{array}{c}\text { Low } \\
(2-3)\end{array}$ & $\begin{array}{c}\text { Tolerable } \\
(4-5)\end{array}$ & $\begin{array}{l}\text { Heightened } \\
\text { (6) }\end{array}$ & $\begin{array}{c}\text { Significant } \\
\quad(7-8)\end{array}$ & $\begin{array}{l}\text { High } \\
(9-10)\end{array}$ \\
\hline \multirow{2}{*}{ Initial risk } & Number & 0 & 4 & 5 & 18 & 7 & 1 \\
\hline & Percentage & 0 & $11.4 \%$ & $14.2 \%$ & $51.4 \%$ & $20 \%$ & $28 \%$ \\
\hline \multirow{3}{*}{ Secondary risk } & Number & 0 & 34 & 1 & 0 & 0 & 0 \\
\hline & & & & & & & \\
\hline & Percentage & 0 & $97 \%$ & $3 \%$ & 0 & 0 & 0 \\
\hline
\end{tabular}


- Secondary risk assessment (R2): the risk of the $100 \%$ operational procedures proved to low and tolerable level.

4) Risk assessment of the port storage (warehousing) operational procedures

- Initial risk assessment (R1): the risk of the $40 \%$ of operational procedures proved to be higher than ALARP level.

- Secondary risk assessment (R2): the risk of the $100 \%$ operational procedures proved to low and tolerable level.

5) Risk assessment of the ship loading/discharge operational procedures

- Initial risk assessment (R1): the risk of the $100 \%$ of operational procedures proved to be higher than ALARP level.

- Secondary risk assessment (R2): the risk of the $100 \%$ operational procedures proved to low and tolerable level.

- Final consequence and finding of the risk assessment of the current operational procedures in SINA Container Terminal, Bandar Abbas port will be shown on Figure 4.

\section{The Findings of the Risk Assessment of the Operational Occupation in SINA Container Terminal}

Following the risk assessment of the operational procedures of the SINA Container Terminal in Shahid Rajaee Port (Bandar Abbas Port) [14] using P\&HRAM and establishing the risks with assigning relevant figures, a number of appropriate recommendations were given as to how to cope with and minimize the identified risks.

As shown in the Table 3, frequency was multiplied by the severity of the risk and the result was assumed to the risk figure of each operational occupation process and the level of each was established using P\&HRAM. The results are showing in the Table 5.
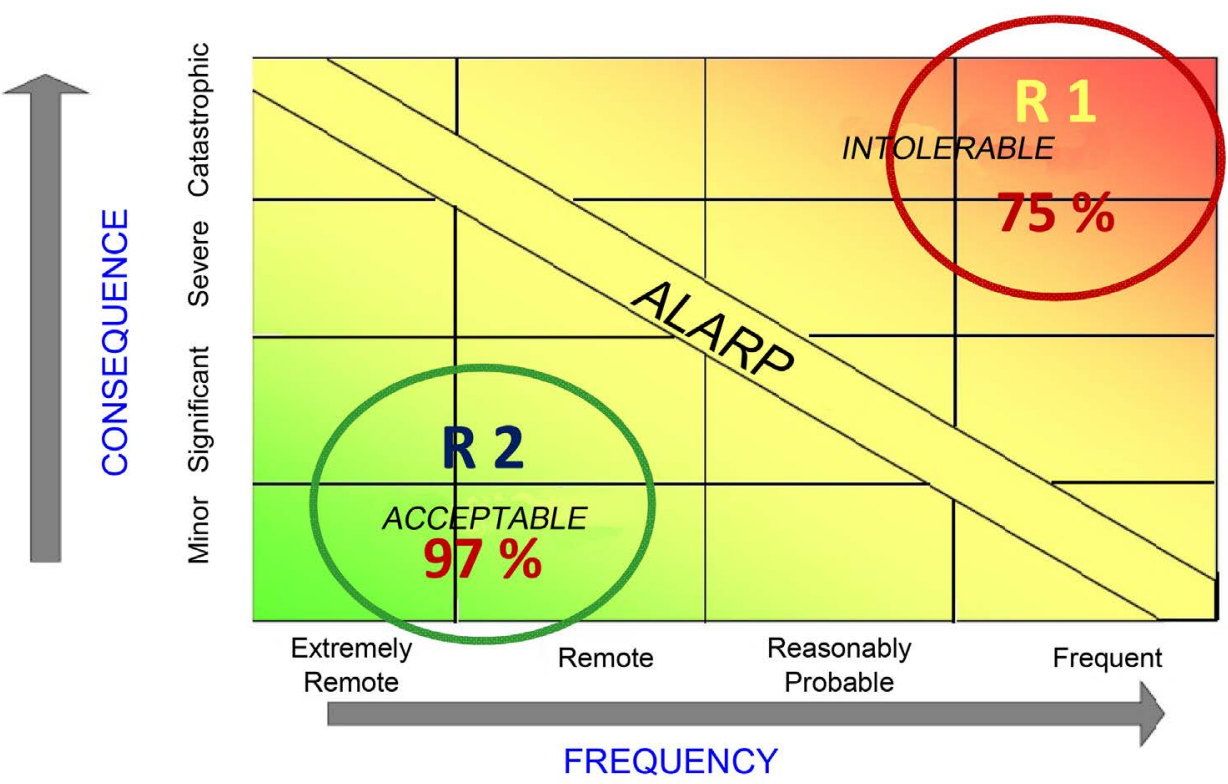

Figure 4. Consequence of the risk assessment of the operational procedures. 
Table 5. The results of the risk assessment of the operational occupation in SINA Container Terminal, Bandar Abbas port on the basis of the type of procedure.

\begin{tabular}{cccccccc}
\hline \multicolumn{2}{c}{ Risk consequence } & $\begin{array}{c}\text { Negligible } \\
(\mathbf{0}-\mathbf{1})\end{array}$ & $\begin{array}{c}\text { Low } \\
(\mathbf{2}-\mathbf{3})\end{array}$ & $\begin{array}{c}\text { Tolerable } \\
(\mathbf{4}-\mathbf{5})\end{array}$ & $\begin{array}{c}\text { Heightened } \\
(\mathbf{6})\end{array}$ & $\begin{array}{c}\text { Significant } \\
(\mathbf{7}-\mathbf{8})\end{array}$ & $\begin{array}{c}\text { High } \\
(\mathbf{9}-\mathbf{1 0})\end{array}$ \\
\hline \multirow{3}{*}{ Initial risk } & Number & 0 & 10 & 122 & 83 & 0 & 21 \\
& Percentage & 0 & $4.2 \%$ & $51.6 \%$ & $35.1 \%$ & 0 & $8.8 \%$ \\
\multirow{2}{*}{$\begin{array}{c}\text { Secondary } \\
\text { risk }\end{array}$} & Number & 6 & 199 & 25 & 6 & 0 & 0 \\
\hline
\end{tabular}

\section{Clarification on the Results of the Risk Assessment of the Operational Occupations in SINA Container Terminal, Bandar Abbas Port}

The risk assessment in the container terminal shows that out of 236 operational procedures in the terminal some 104 procedures (45\%) are higher than ALARP and 122 procedures fall within the scope of ALARP. This indicates that the operation in the terminal is high risk requiring control measures to lower the risk. After implementation of the recommended control measures, it was seen that the risk of all operational declined more than $90 \%$ to tolerable level in a way that continuation of the activities in the terminal can take place without a particular problem. On the basis of the results of the risk assessment in different stages, the procedures will be as following:

1) Risk assessment of the ship operational procedures ( 80 operational occupations)

- Initial risk assessment (R1): the risk of the $37 \%$ of operational procedures proved to be higher than ALARP level.

- Secondary risk assessment (R2): the risk of the $97 \%$ operational procedures proved to low and tolerable level.

2) Risk assessment of the berth operational occupations (30 operational occupations)

- Initial risk assessment (R1): the risk of the $44 \%$ of operational procedures proved to be higher than ALARP level.

- Secondary risk assessment (R2): the risk of the $100 \%$ operational procedures proved to low and tolerable level.

3) Risk assessment of the port areas operational occupations (76 operational occupations)

- Initial risk assessment (R1): the risk of the $57 \%$ of operational procedures proved to be higher than ALARP level.

- Secondary risk assessment (R2): the risk of the $96 \%$ operational procedures proved to low and tolerable level.

4) Risk assessment of the port storage (warehousing)operational occupations (23 operational occupations)

- Initial risk assessment (R1): the risk of the $40 \%$ of operational procedures proved to be higher than ALARP level.

- Secondary risk assessment (R2): the risk of the $100 \%$ operational procedures proved to low and tolerable level. 
5) Risk assessment of the ship loading/dischargeoperational occupations (27 operational occupations)

- Initial risk assessment (R1): the risk of the $35 \%$ of operational procedures proved to be higher than ALARP level.

- Secondary risk assessment (R2): the risk of the $100 \%$ operational procedures proved to low and tolerable level.

6) Final consequence and finding of the risk assessment of the operational occupation in SINA Container Terminal, Bandar Abbas port will be shown on Figure 5.

\section{Conclusions}

Question 1: What are the main risks threatening human lives in SINA container terminal (Bandar Abbas Port)?

As demonstrated by the operational risk assessment the main risks threatening the human lives in operational procedures in different sections include:

- Ship Operation (loading/discharge): the fall of the heavy items, gantry crane and the lid of the ship hatch as well as fall of the gantry crane, severe weather condition, unbalanced weight of container and the wire of the spreader.

- Berth operation procedures: gantry cranes, equipment and machineries, awkward cargo, other equipment, weighting equipment.

- Yard operation procedures: reach stacker, vehicles moving around, spreader wires, equipment and machineries, dangerous goods containers, unsafe working condition and unfavorable weather condition.

- Storage/warehousing procedures: scale next to the warehouse, cargo train, vehicles moving around, rough ground, lift track, worn-out wires, inappropriate stowing of

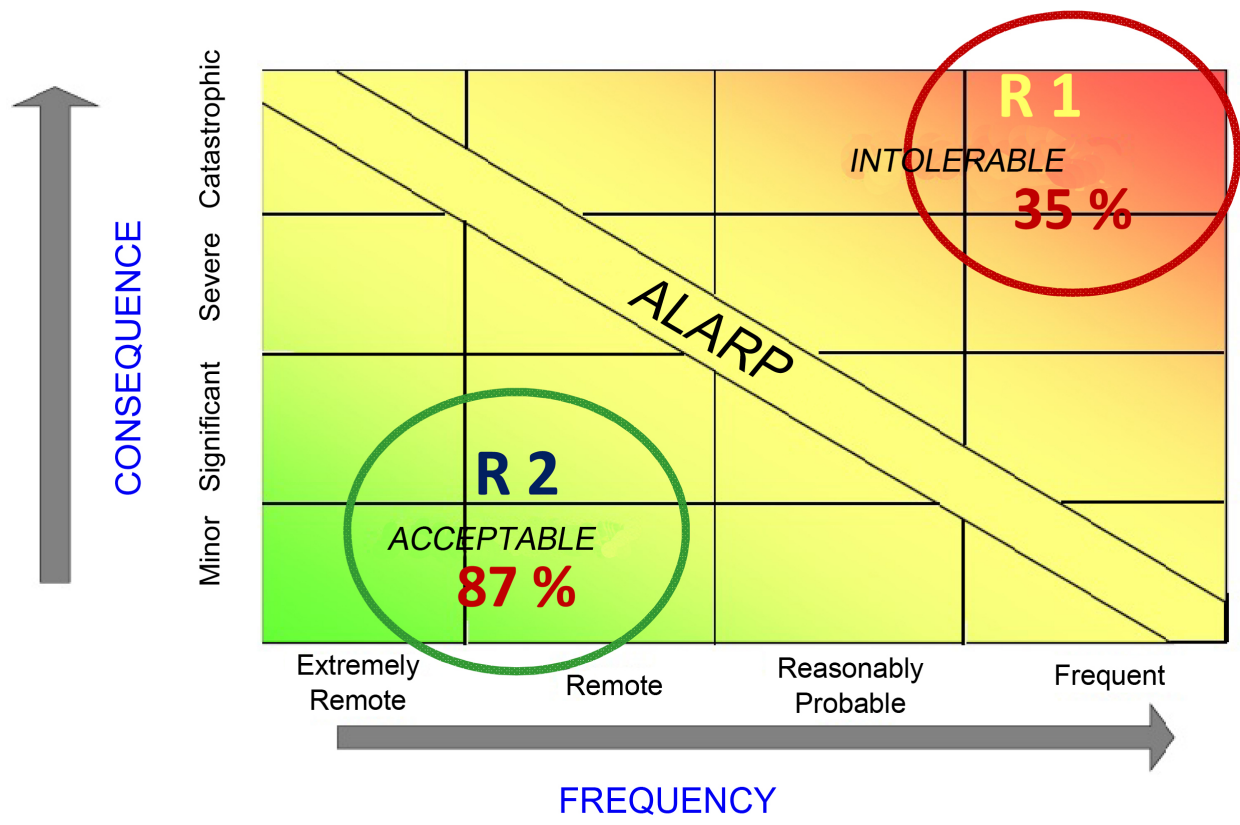

Figure 5. Consequence of the risk assessment of the operational occupation. 
cargo inside the container, unavailability of MSDS, lift track and reach stacker/top lift.

- Gate operation procedures: containers, vehicles carrying container.

Question 2: What is the most effective corrective measure for minimizing the risks in SINA Container Terminal (Bandar Shahid Rajaee)?

\section{Comprehensive Safety Measures Recommendations}

- Severity and frequency of an incident represent two helpful factors to establish the priority of the risks. Less frequent risks are more tolerable.

- The costs of risk mitigation of the old systems are greater and afford higher priority in terms of taking safety measures.

- If a risk cannot be removed in design stage, it should be minimized by different tools and options to a tolerable level.

- If a risk cannot be removed, it should be minimized using safety engineering. It is recommended that periodical inspections in respect of safety tools maintenance should be conducted.

- In case the safety control measures fail to mitigate the risk, necessary tools need to be employed to detect dangerous situations and warn the staff and workers against them.

- Management control methods such as development of guidelines and staff training should be used given the fact the human errors as the most important factor in occurrence of the incidents are more frequent than electronic technical failures.

- Some degree of risk should be accepted.

- Conducting the periodical assessment and complementary methods.

\section{References}

[1] Maritime Safety Authority of New Zealand (2004) Final Guidelines for Port \& Harbors Risk Assessment and Safety Management System. Maritime Safety Authority of New Zealand, Russell Killington.

[2] Marlborough District Council (2013) Review of Risk Mitigation Summary Report. Marlborough District Council, Wellington.

[3] Safarzadeh, M. (2006) Maritime Transportation Volume 1, Ports and Maritime Organization. Daneh Publication, Asrareh.

[4] Hasanzadeh, M.A. (2008) Port Safety Management, Volume 1. Ministry of Road and Transportation Research Center, Tehran.

[5] Dockyard Port of Plymouth (2014) Hazard Ranked Risk Assessment.

[6] UK Department for Transport (2012) Port Marine Safety Code.

[7] Arsalan, S. (2004) Port Safety Guidline, Volume 1, Ports and Maritime Organization. Danesh Publication, Asrare.

[8] Hadiyan, M. (2008) Modern Method in Minimization of Risks on the basis of the Safety in Ports. The $4^{\text {th }}$ National Port Safety Seminar.

[9] Hamidi, H. (2008) Safety Management in Shipping Industry, Volume 1. Ministry of Road and Transportation Research Center, Tehran. 
[10] Hasanzadeh, M.A. (2004) The Role of the Safety Management System in Promotion of Port Safety. The $1^{\text {st }}$ National Port Safety Conference Article Collection, Ports and Maritime Organization Publication.

[11] Legal Department, Ports and Maritime Organization (2008) Port and Maritime Rules and Regulations, Vol. 1. Public Relations, PMO.

[12] Helmseresht, P. and Delpisheh, I. (1995) Work Health and Environment Health Principles. Chehr Publication, Tehran.

[13] Iranian Oil Company (1994) Registration Guidelines, Research, Incident Analysis, HSE Management.

[14] Rouineh, R. and Mohammadfam, I. (2011) The Comparison of the Risk Assessment Using the Method of FTA and FMEA in Shahid Rajaee Container Terminal. $7^{\text {th }}$ Conference of the Safety and Environment Health.

http://www.civilica.com/Paper-NCOHS07-NCOHS07 095.html

\section{Submit or recommend next manuscript to SCIRP and we will provide best service} for you:

Accepting pre-submission inquiries through Email, Facebook, LinkedIn, Twitter, etc.

A wide selection of journals (inclusive of 9 subjects, more than 200 journals)

Providing 24-hour high-quality service

User-friendly online submission system

Fair and swift peer-review system

Efficient typesetting and proofreading procedure

Display of the result of downloads and visits, as well as the number of cited articles

Maximum dissemination of your research work

Submit your manuscript at: http://papersubmission.scirp.org/

Or contact oje@scirp.org 